\title{
From Saul the Pharisee to Paul the Apostle: The Conversion of Paul, a Prototype for Africans' Conversion to Christianity?
}

\author{
Elia Shabani Mligo ${ }^{1}$ ii \\ ${ }^{1}$ Faculty of Humanities, Arts and Social Sciences, Teofilo Kisanji University, Mbeya, Tanzania.
}

\begin{abstract}
This article grapples with the question of the relevance of Paul's conversion in Acts 8-9 in relation to the current African conversion to Christianity. While for many years, scholars have considered the conversion of Paul on his way to Damascus as a proto-type for people's conversion to Christianity from other religions, this article argues that it can hardly be regarded in that way for African people's conversion from African Traditional Religion (ATR) to Christianity due to the nature of ATR and its major emphasis. Christianity mostly emphasizes "other-worldly" affairs neglecting "this-worldly" affairs of humanity being conceived as a religion of the "hereafter," the heavenly religion having little to do with thisworldly affairs. Instead, ATR, due to its concern about people's current world's predicaments becomes a religion favored by most Africans even after their conversion to Christianity.
\end{abstract}

\author{
Correspondence: \\ Elia Shabani Mligo \\ Email: eshamm2015@gmail.com \\ Publication History \\ Received 28th December, 2020, \\ Accepted 19 January, 2021, \\ Published online 26th January, \\ 2021.
}

Keywords: Paul's Conversion, Prototype, Christian Conversion, African Traditional Religion.

\section{INTRODUCTION}

In the introduction to his article "Conversion in Its Cultural Context," Gration writes: "In a very true sense every conversion is in context, a context that is multifacetedly embracing the political, social, economic, and religious domain in which a person is living at the time of his or her conversion. Thus whatever the meaning of conversion, it never takes place outside a cultural context." Looking at the Damascus Event, one can easily understand what happened to Paul of Tarsus in the capital of Cilicia (Acts 21: 39), as a contextual event. Before his encounter with Jesus (Christophany), Paul was a Jew in a Hellenistic world; Paul boasts himself of the context he belonged: "If any other man thinks he has reason for confidence in the flesh, I have more: circumcised on the eighth day, of the people of Israel, of the tribe of Benjamin, a Hebrew born of Hebrews; as to the law a Pharisee, as to zeal a persecutor of the church, as to righteousness under the law blameless." (Phil 3: 4-6 Revised Standard Version). ${ }^{2}$ These words indicate that before his encounter with Jesus, Paul was recognized by his community as a reputable person educated under a reputable teacher of the Mosaic Law and Jewish traditions; he was converted while in his Jewish community and remained a Jew with a new status within his community.

This article deals with Paul's conversion experience and its relevance to African conversions from African Traditional Religion to Christianity. The major question which is addressed is whether Paul's conversion experience on his way to Damascus can be a prototype for African people's conversion from ATR to Christianity. The article argues

\footnotetext{
John A. Gration, “Conversion in Cultural Context,” International Bulletin of Missionary Research, (1983): 157 cf. Michael Amaladoss, "Religious Conversions: An Indian Christian Point of View," Hindu Christian Studies Bulletin 15 (2002): 4-5; David A. Snow \& Richard Mechalek, "The Sociology of Conversion," Annual Review of Sociology 10 (1984); David A. Snow \& Richard Mechalek, "The Convert as a Social Type," in Sociological Theory, ed. R. Collins (San Fransisco: Jossey Bass, 1983).

2 The "zeal" for the law was a characteristic of Jewish life. One can note the zeal for the law to various people and groups: "Simeon and Levi (Judith 9:2-4), Elijah (cf. 1 Kings 18:40; 19:10,14), Mattathias (1 Macc 2:23-26), and Phineas (cf. Num 25:7-11), defended the Torah as the definitive norm of Jewish life (cf. Sir 48:2; 1 Macc 2:54, 58). Zeal for the Torah as the predominant mark of the Jewish way of life was not only characteristic of militant Zealots but also determinative for the Essenes (cf. 1QS 4:5-6, 17-18) and for radical Pharisees such as Saul." (Honore Sewakpo, "A Comparative Analysis of Pre-Conversion of Paul in Acts 8-9 and Boko Haram Insurgence in Nigeria: Implications for National Unity (n.d.): 4-5. These people and groups maintained the Israel's "zeal” for holiness, to maintain the Israel's identity as Yahweh's selected people.
} 
that though Paul's conversion from Judaism to Christianity has been conceived as a prototype for people's conversion to Christianity from other religions, that conception is hardly effective to Africans and their ATR context. The starting point for this argument is Paul's life before conversion, then after his conversion, a discussion of the phenomenon of conversion as a process not only a sudden change and the final illustration of incompatibility between Paul's and Africans' conversion experiences.

\section{Paul's State before Conversion}

Sewakpo summarizes the state of Saul before his conversion based on the accounts provided in the book of Acts: "(i) Saul goes from house to house in Jerusalem and has both men and women thrown into prison (Acts 8:3); (ii) he advocates the death penalty against Christians (cf. Acts 22:4; 26: 10); (iii) he forces them to renounce their faith (cf. Acts 26:11); (iv) he has Christians whipped with the lash (Acts 22:19); and (v) he has himself deputised to persecute Christians as far away as Damascus (cf. Acts 9:2)." ${ }^{\prime 3}$ The summarized account indicates that Paul had a mission against Christianity to hinder its existence and the anticipated malicious effects if tolerated to continue.

What forced Saul to engage in persecuting Christians, people of a different sect from the Jewish religion he belonged? As noted above, Saul belonged to a particular context, sharing the beliefs and practices of the group he belonged to. As a learned Jew, a Pharisee in zeal, Saul was overwhelmed by the scandal of the cross: How could Jesus be the Messiah, as confessed by Jesus' followers (people of the Way), the one crucified and died on the Roman cross? For him, and for the Jewish group he belonged, the crucifixion and death of the acclaimed Messiah was a scandal that led to the persecution of Jesus' followers as being heretics (cf. 1Cor 1: 23; Gal 5: 11). Saul saw that nowhere in the Torah was a witness of the crucified Messiah. ${ }^{4}$

It means that Saul, as a Jew sharing the faith of his fellow Jewish contemporaries, had a different understanding of the Messiah from that of the followers of Jesus. Saul waited for the Anointed One- the Messiah - to come with enormous power. As a Pharisee, Saul strictly adhered to the Jewish religion and his Pharisaic interpretation of the Torah and the anticipated Messiah. Saul believed that the Messiah could conquer the Roman Empire and the whole world. The Messiah could not die a shameful death in the hands of his enemies as Jesus did because the Jewish Scriptures testified that any person hanged on a tree is cursed (Deut 21: 23). Saul did not tolerate the emergent sect that claimed Jesus, the crucified person, as being Messiah and the allegiance to Jesus paid by this conceived heretic sect. Despite being false, according to Jewish understanding, Saul saw this sect and the message about Jesus which this sect had as being a "stumbling block" (1Cor 1: 23). Saul was zealously determined and had official support to extinguish this group and its adherents before it threatened the existing Jewish faith. ${ }^{5}$

Sewakpo summarizes the above accounts of Saul's status before conversion and the reasons for Saul's engagement in the persecution of the emerging new sect. His engagement was to go against the following issues upheld by the new sect: "(i) the claim that a crucified man was being proclaimed as Messiah; (ii) the Hellenists' revival of Jesus' critique of the Temple (Acts 6:14). (iii) the death of Christ was for Saul an epiphany of sacred violence. He realised that his kind of religious observance was a service of the primitive sacred within a system of sacred violence; and (iv) Saul saw the first Christians as abusing and abandoning the law, the very centre of his religion as a scrupulous Pharisee, and therefore, threatening Judaism, itself." "Therefore, Saul being exceedingly zealous for the traditions of his ancestors (Gal 1: 14) longed to extinguish the emerging Christian sect before it brought some negative effects to the existing Judaism. Saul was convinced that he was doing God's work by endeavouring to purify Judaism through extinguishing the considered dangerous and dreadful heresy of the emerging Christianity.

\section{Saul's State after Conversion}

Having described Saul's status before the Damascus Event, what can be said about his status after the Damascus Event? The exact words that can be ascribed to him are his change of status and his change of context. He changed from being Saul the Pharisee to being Paul the Apostle of Jesus. Paul does not, whatsoever, refer in his epistles to his encounter with Jesus as being a conversion, repentance, or turning though there are some biblical texts which only allude to the event (Gal 1: 11-17; Phil 3: 2-11; and Rom 7: 13-25). Moreover, Paul hardly mentions the trip to Damascus and what exactly transpired in that trip within his epistles. "However, the descriptions in Galatians (1: 13-17) and Philippians (3: 4-7) suggest that what Paul experienced was a change of commitment, values and identity that was sudden and unexpected." Peace clearly notes: "To be sure, Paul does not recount in detail in his epistles the events of his conversion. The trip to

\footnotetext{
Sewakpo, "A Comparative Analysis," 1.

Richard V. Peace, Conversion in the New Testament: Paul and the Twelve (Grand Rapids, MI: William B. Eerdmans, 1999): 20; 41-44.

Peace, Conversion in the New Testament, 20.

Sewakpo, "A Comparative Analysis," 4.

Marcel Owineza, “The Conversion of St. Paul,” Thinking of Faith: The Online Journal of British Jesuits 2 (2011) accessed June $26,2020$.

https://www.thinkingfaith.org/articles/20110125 1.htm
} 
Damascus is not mentioned by him (though Damascus is noted in Gal. 1: 17), and none of the miraculous events are noted (light, voice, blindness)." 8 Despite not recounting the Damascus experience in his epistles, "he consistently leaves the impression that this change was sudden and unexpected, although he never says so explicitly or directly."

Though Paul hardly mentions the term "conversion" in his epistles, scholars consider his Damascus experience as a model of conversion, a change of the individual's behaviour. It is seen as being a prototype of people's conversion to Christianity from other religions ${ }^{10}$ while others consider it as a call to ministry, a change in ministry from being a defender of Judaism and its tenets to being a defender of Christianity and its tenets. ${ }^{11}$

The question of whether Paul's Damascus experience was a conversion or a call was first raised by Krister Stendahl in his lecture series entitled "Paul among Jews and Gentiles" capitalizing to the point that the accounts of the Damascus Event emphasize on the call of Paul to a specific task-a mission to the Gentiles. Stendahl's own words recount: "The emphasis in the accounts is always on this assignment, not on the conversion. Rather than being 'converted,' Paul was called to the specific task - made clear to him by his experience of the risen Lord — of apostleship to the Gentiles, one hand-picked through Jesus Christ on behalf of the one God of Jews and Gentiles." ${ }^{2}$ Here Stendahl is of the opinion that Paul's experience was a call to ministry and not a conversion.

In whatever way the model is conceived, it is criticized for being inconsistent in its applicability as it hardly considers other religious changes of a similar type. For example, the conversion of the twelve disciples into being followers and committed apostles of Christ and that of the 3000 converts at Pentecost hardly had a similar experience with that of Paul. Moreover, the concept of "call" to ministry is also a multifaceted concept that hardly escapes the concept of conversion. One can hardly be called from one religion to serve into another religion without being transformed to conform to the new religion. In that case, both terms of conversion and call ascribed to Paul's Damascus experience involve one's changes or transformation from one's former religion to the new religion without totally rejecting the old religion. Paul's Damascus experience involved a transformation from Judaism to Christianity while reinterpreting Judaism for Gentiles and Jews to understand it in a new perspective. Peace seems to be right when he states that "Rather than speaking about conversion or call, it is more accurate to speak about conversion and call." 13 Paul was converted from Judaism to Christianity at the encounter with Jesus (Christophany) (Acts 9: 3-7), and then called to perform a particular Christian task (Acts 9: 15). Therefore, according to Peace, both events happened simultaneouslyhis conversion was followed by his commission to what he had to accomplish in his Christian life. ${ }^{14}$

\section{Paul's Conversion as a Prototype for Christian Conversion}

Despite the above criticism, the conversion of Paul in his way to Damascus holds a significant recognition in the Christian tradition. Peace states this recognition clearly: "Paul's conversion is significant in yet another way. For countless people in countless generations, it has provided the model of what Christian conversion is supposed to be like. Whether individuals have always focused on the key elements in this experience or gotten sidetracked into secondary issues (such as conversion must sudden to be valid) is beside the point. For many in the church, this is what conversion looks like in its pure form." 15

How can Paul's conversion be recounted as a prototype for people's conversion to Christianity from other religions? As has just been stated in the previous paragraphs, the exact definition of the concept of conversion is hard to attain. However, Peace alludes to it when he states what stands at the core of this concept: "At the core of the concept of conversion is the idea of turning. On one side of that turning are the conditions that facilitate or enable the turning to take place (insight). On the other side of the turning is the outcome or result of the turning (transformation)."'16

8 Peace, Conversion in the New Testament, 34.

10 Richard N. Longenecker (ed.). The Road from Damascus: The Impact of Paul's Conversion on His Life, Thought and Ministry (Grand Rapids, MI: William B. Eerdmans, 1997); cf. Lovemore Togarasei, The Bible in Context: Essay Collection. BiAS 1 (Bamberg: University of Bamberg Press, 2009 ): 100.

11 David Jacobus Bosch, Transforming Mission: Paradigm Shifts in Theology of Mission (New York, NY: Orbis, 1991); cf. Stendahl, Krister. Paul Among Jews and Gentiles and other Essays (Philadelphia: Fortress Press, 1976): 7-22; James D.G. Dunn, Jesus, Paul and the Law: Studies in Mark and Galatians. (Philadelphia: Westminister, 1990): 89-104; Beverley R. Gaventa, From Darkness to Light: Aspects of Conversion in the New Testament (Philadelphia: Fortress, 1986); John J. Pilch, "Paul's Ecstatic Trance Experience near Damascus in Acts of the Apostles." HTS Teologiese Studies/Theological Studies 58, no. 2 (2000): 697 \& Johannes Munck, Paul and the Salvation of Mankind (Atlanta, GA: John Knox, 1959): 24-35.

12 Stendahl, Paul Among Jews, 7; cf. "The Apostle Paul and the Introspective Conscience of the West." Harvard Theological Review 56, no.3 (1963); Peace, Conversion in the New Testament, 27 \& Pilch, "Paul's Ecstatic Trance," 697.

13 Peace, Conversion in the New Testament, 29; cf. David Thang Moe, "Themes and Methodologies in Pauline Missiology for a Contemporary World." Missionalia 45, no.2 (2017): 100-102; Ezekiel Mokwele Katiso Mathole, "The Christian Witness in the Context of Poverty: With Special Reference to South African Charismatic Evangelicals" (PhD Thesis, University of Pretoria, South Africa, 2005): 135-141.

14 Peace, Conversion in the New Testament, 29.

15 Peace, Conversion in the New Testament, 19; cf. Togarasei, The Bible in Context, 98-99; Lovemore, Togarasei. "The Conversion of Paul in the Light of the Theory of Cognitive Dissonance."Zambezia XXXI, no. i/ii (2004): 124; cf.Kilbourne, Brock \& Richardson, James T. "Paradigm Conflict, Types of Conversion, and Conversion Theories.” Sociological Analysis 50, no.1 (1988) 1.

16 Peace, Conversion in the New Testament, 37; Snow \& Mechalek, "The Sociology of Conversion," 70-71; Snow \& Mechalek, "The Convert as a Social Type"; Mathole. "The Christian Witness," 135-141. 
Therefore, following this allusion, Paul's conversion can be seen as a "process" not a mere "sudden change".

\section{Paul's Conversion as a Three-Phase Process}

As Peace alludes the definition of the concept of conversion in the above paragraph, the process of Paul's turning (conversion) begins with his assessment of self, his insight on what he, in one way or another, participated as a member of the Jewish society that was not pleasing to God: being zealous to the law in a Pharisaic manner, his inner struggle regarding his behavior, and his participation in issues relating to murder, for example, that of Stephen and that of Christians in Jerusalem and other places. ${ }^{17}$ All the stated events more likely made Paul assess himself and his true status before the God he serves. The conversion process culminates with Paul's encounter with Jesus, the crucified Lord, a man who, according to his Jewish understanding was crucified on the Roman cross. After the dialogue between Jesus and Paul (Acts 9: 4-6), Paul reaches a turning point. Paul turns "from the law to Christ, from persecutions [of Christians] to apostleship, from killing Jews who had become Christians to calling Gentiles to become Christians. In other words, Paul changed from being a Jewish apostolos of shalia (the one who is sent by the Sanhedrin in order to bind followers of Jesus and send them to Jerusalem) (Acts 9: 1-2) to a Christian apostolos (the one who is sent by Jesus to preach the gospel to Gentiles (Acts 9: 15). He changed from being an apostle of the Jewish Sanhedrin to being an apostle of Jesus Christ. He also changed from being the herald of "works of righteousness" to an uncompromising preacher of "righteousness by faith." This is what lies at the heart of the word 'conversion'- the image of turning. There is a 'from and a to.' Paul left behind one image of how to serve God (by persecuting those who deny the law) and took up a new image of how to serve God (he was appointed to 'serve and testify' [Acts 26:16]). He left behind one view of Christ (a rebel and a pretender) and took up a new view (the Messiah and the Son of God)." 18 Therefore, three phases characterize Paul's conversion event: first, his own insight — his own examination of his state before God; second, his own turning point - his own encounter and dialogue with Jesus, and third his transformation - his incorporation in the Christian community of believers and the acceptance of his call for a specific duty to Gentiles. ${ }^{19}$

\section{Baptism as a Symbol of Conversion to Christianity}

Having discussed the conversion of Paul in the above headings, the article looks at contemporary experiences of conversion and a symbol of that conversion. One of the important symbols of conversion to Christianity is "water baptism." Water baptism symbolizes "the identification with Christ and the transfer of allegiance" to him (see Rom 6: 3-4) ${ }^{20}$ What does it mean by identifying with Christ and transferring allegiance to him through baptism? It means that "To become a Christian is to identify with Christ - the person of Christ, the life, death and resurrection of Christ, the mission of Christ in the world." ${ }^{21}$ It is to use one's freewill to empty and surrender oneself to Christ's wills and his sovereign power. ${ }^{22}$ Therefore, a converted African from ATR, Islam or any other religion requires surrendering the whole of his or her life to Christ and being baptized as a symbol of belonging to Christ's flock. The convert to Christianity belongs to Christ and is not expected to patronize ideas and practices from the former religion.

\section{From ATR to Christianity: Why Africans Patronize ATR Practices?}

How can one account for the Christian baptism among Africans belonging to African Traditional Religion (ATR) as a sign of conversion? Does conversion to Christianity make them fully followers of the Christ they confess as Lord and Saviour during their baptismal symbolism? These questions are important if there is the need to understand the conversion experiences of most Africans in the midst of their African religious context. Banda states, "African Christians truly want to be authentic Christians exclusively committed and reliant upon Christ. They are driven into syncretism because, to them, Christ seems to be either detached from them or insufficient to address their immediate African problems. African Christians continue to retain a firm hand on African Traditional Religions, because they see them 'as meeting real needs by procuring salvation from social ills, the evil spirits and witchcraft, which they experience as 'real,' while Christianity is sought to provide salvation in the hereafter."' 23 Therefore, basing on two researches within the African context, the author illustrates the above-claim. He also shows that the conversion of Africans from ATR to Christianity can hardly be seen in light of Paul's conversion from Judaism to Christianity.

\footnotetext{
17 Peace, Conversion in the New Testament, 41-55;

18 Peace, Conversion in the New Testament, 100.

19 Peace, Conversion in the New Testament, 100; cf. Lovemore Togarasei, "The Conversion of Paul," 128-134; Tuba Boz, "Religious Conversion, Models and Paradigms." Epiphany: Journal of Transdisciplinary Studies 4, no.1 (2010): 131-132; \& Mathole, "The Christian Witness," $135-141$.

20 Gordon T. Smith, Beginning Well: Christian Conversion and Authentic Transformation (Downer Grove, IL: VIP Books, 2001 ): 118.

Smith, Beginning Well, 118.

Smith, Beginning Well, 118

23 Collium Banda, "The Sufficiency of Christ in Africa: A Christological Challenge from African Traditional Religions" (MTh Thesis, University of South Africa, 2005): 7 .
} 


\section{Christianity at the encounter with the Rangi People of Tanzania}

Cox researched the Rangi of Haubi village in Kondoa Tanzania to ascertain the reasons for Rangi people to continue practising ATR values despite the existence of Christianity for a long time in the village. Cox's research indicated that though the Rangi people converted to Christianity after the arrival of missionaries in the area around 1907, most of them hardly jettisoned African traditional practices. They continued practising ATR practices despite their baptism and vows of allegiance to Christ. Some of the reasons which Cox notes in his research include the following: first, Christians at Haubi village converted to Christianity mostly for material gain, not because they had the gospel preached by missionaries to them. It was because of materials which they anticipated to gain from it. Cox further reports that most of the Rangi people could not contain the slave trade which continued in the area; and since Christian missionaries had rifles, most of the Rangi people converted to Christianity as refugees from being seized by slave traders. ${ }^{24}$ In his words, Cox recounts: "One of the biggest reasons for Rangi believers to engage in ATR is because Christianity was not adopted for theological reasons. Rangi people did not hear the gospel as preached by the Catholic priests and intellectually agree that such beliefs were 'better' than their ATR beliefs. Many, if not most, accepted Christianity because of the material benefits that it brought. Weapons were now available to defend themselves from slave traders, trade goods were now available and friendly contacts with the outside world was now established." 25

Second, Christianity was conceived as being a foreign religion within the Haubi land. Cox notes that though Christianity existed in Haubi village for more than 75 years, many people being baptized married and buried by the Church, yet Christianity remained foreign to their eyes in various ways: strange names provided to their children, strange ways of worship different from those in ATR, strange ways of providing health and educational services. This strangeness of various practices of Christianity made Christianity enigmatic to fully embrace it as they lived in their native ATR. ${ }^{26}$

Third, Christianity had no relevance to the lives of Rangi people. Since their African traditional lives were populated by rituals, they hardly found helpful rituals in Christianity as was in ATR. Cox states that in the Rangi traditional life "There are rituals for purifying a woman after childbirth, for smelting iron, for welcoming in the New Year, for beginning the harvest, for purifying a man after sexual activity, for announcing a marriage and many more."27 All these rituals were not found in the Christian tradition. Very few rituals similar to those practised in ATR were found in Christianity. Christian rituals were "almost exclusively limited to the sacraments, church holidays and the order of the church service itself." ${ }^{28}$ Consequently, Rangi Christians resorted to their African traditional rituals to resolve some of the issues which the Christian religion failed to provide answers to them. Cox further states: "As a result of a Christian alternative to these rituals, Rangi Christians in effect, operated on two different planes. In the church building, they follow the rituals (sacraments and holidays) that the priests first taught them. For the traditional rituals that the Church did not address, they continued with their traditional practices." 29

Fifth, Christianity lacked effectiveness in Rangi people's lives. There were some problems that Christianity hardly resolved. These made the Rangi consult traditional healers for help. If they were attacked by spiritual beings, if children did not succeed in their studies, if businesses did not flourish, etc., Christians consulted their Church; the failure of the Church to provide solutions led them to consulting the ATR for solutions it could offer.

Moreover, one of the major threatening issues leading the Rangi people's resort to ATR is the scourge of illnesses. Poverty and most Rangi people's inability to pay for the hospital medicines easily convinced them to turn to ATR for help. Cox puts it: "When sickness strikes, as it often does, Rangi will go to the clinic for medical help. Supply of drugs are limited, and they may or may not have the medicine that is needed. They will ask a priest to pray for them, but their search for a cure does not end there. They will also seek help in ATR. This is because they are unable to pay for the medicine (...)." ${ }^{30}$

In addition to the above points, Cox reports that the view of most Rangi people regarding Christianity and ATR favoured them to continue with ATR while confessing Christianity. ATR did not prohibit them from being syncretistic. It means that one could be a devout Christian, yet practising ATR without being condemned by the ATR of doing something wrong.

\footnotetext{
24 Richard Cox, "Why Rangi Christians Continue to Practice African Traditional Religion? GIALens 3 (2008), accessed April 15, 2020. http://www.gial.edu/GIALens/issues.htm

25 Cox, "Why Rangi Christians Continue to Practice African Traditional Religion; cf. Josephat Alphonce Rweyemamu, "Conversion in Missionary Christianity, Northwest Tanzania: A Critical Assessment of Methods and Their Impact on Haya Christian Life" (PhD Thesis, University of Stellenbosch, South Africa, 2012): 184-193.

26 Cox, "Why Rangi Christians Continue to Practice African Traditional Religion?

27 Cox, "Why Rangi Christians Continue to Practice African Traditional Religion? 7 cf. Ghansah, William Ekow, Ghansah, "Encounters between Christianity and African Traditional Religion in Fante Funeral Practices: A Critical Discussion of the Funeral Practices of the Fante in Ghana," M.Phil. Thesis, University of Oslo Norway, 2012.

28 Cox, "Why Rangi Christians Continue to Practice African Traditional Religion?" 7

29 Cox, "Why Rangi Christians Continue to Practice African Traditional Religion?" 7

Cox, "Why Rangi Christians Continue to Practice African Traditional Religion?" 7
} 
Moreover, people conceived of Christianity as a religion relevant for the "afterlife" while ATR for the present life. Christianity did not show any impact to people's lives as had ATR. Cox avers: "For many Rangi Christians, Christianity is something that has relevance for the afterlife. One becomes a Christian and practises the Christian faith not necessarily for any particular benefit today, but for the hope that after death they will be rewarded in heaven." 31 Therefore, the points discussed above indicate that it is as hard to separate an African from his or her African traditional religion as is to separate the fish from water for it to continue having life.

\section{Christianity in the Four States of Western Nigeria}

The previous section has discussed the way the Rangi of Tanzania (East Africa) patronized ATR due to the failure of Christianity to offer what the ATR offered to them. The discussion now advances towards the West African part of Africa and considers a recent research conducted by Akino-Otiko and Abbas and the mass conversion of the Igbo people in Nigeria. ${ }^{32}$ Akino-Otiko and Abbas researched in four states of western Nigeria to ascertain the nature of the interaction that Christians and Muslims had with ATR, the people's native religion. Researchers noted that, as was to the Rangi of Tanzania discussed above, missionaries enticed people to join Christianity through material provision. Akino-Otiko and Abbas write: "To further entice the Africans to leave ATR and their cultural practices, the missionaries engaged in medical care, pastoral visitation and vocational training for young men and women, and all these played an effective part in disposing of many adherents of ATR to abandon both their religion and cultural practices. Most effective of these was the promotion of formal education, which proved to be the most viable and effective instrument of conversion, as it yielded and sustained converts." ${ }^{33}$

According to Akino-Otiko and Abbas, missionaries used two methods of converting people to Christianity: by forcing them to succumb to Christianity and by proselytizing them. By the use of these methods, with the help of the above-stated services provided to convert Christians, missionaries converted a large number of people from ATR to Christianity in the area. As Akino-Otiko and Abbas echo: "It is reported that hundreds of thousands of young men and women who attended such schools also received instructions in the faith, accepted baptism (initiation) while in school and thereby broke the ancestral covenant with any deities (...). [T] he activity led to massive conversion of Africans in the early 1950s upward." ${ }^{34}$ However, Akino-Otiko and Abbas state their observation in the midst of the huge masses of converts to Christianity and Islam: "Although huge numbers have been (and are being) converted from ATR, it has been noted that many African Christians and Muslims make a return to the practice of ATR or patronize it together with their newly found religion (Christianity and Islam)." 35

Togarasei adds that "Today, apart from the missionaries, there are the church clergy and some western-oriented theologians, particularly in mainline and Pentecostal-Evangelical churches, who believe that African culture stands in the way of Christianity. For these people, many African Christians have not converted to Christianity in the true sense of the word. This is because, generally, conversion is understood to be a transition from a 'false' religion to a 'true' religion. However, despite claiming to be Christians many Africans remain practicing African tradition and religion." Togarasei's words indicate that the missionaries' negative mentality towards African culture and values is still persistent in African Christianity through the westernized pastors and theologians.

Since the conversion in the manner of the Damascus event is the "change from one religious state (a terminus a $q u o$ ) to another religion (a terminus ad quem) ${ }^{\prime 37}$ what can one account for the back and forth movement of ATR converts to missionary religions? Akino-Otiko and Abbas's research provides three major reasons for this kind of movement. They state: "The findings confirmed that the patronage of cultural practices does not imply conversion to ATR (...). The result showed that, there is a movement back to ATR and cultural practices for three fundamental reasons; first to seek solutions to physical problems, second to ward off spiritual attacks and third, many Africans still perceive ATR as part of normal customs of the Africans." ${ }^{38}$ Akino-Otiko and Abbas's findings cement the fact that African Christians' return to ATR from the missionary religions, where they converted to, should not be considered as another conversion to ATR; rather, it is a resume to their inborn religion that was not removed by just a simple conversion to a foreign religion. It is a failure of the foreign religion to be both "functionalistic and utilitalianistic," that is, having an inability to effectively

\footnotetext{
31 Cox, "Why Rangi Christians Continue to Practice African Traditional Religion? 7 cf. H. J. Mugabe, "Salvation from an African Perspective." Evangelical Review of Theology 23, no. 3 (1999): 240.

32 Hale, F. "Debating Igbo Conversion to Christianity: A Critical Indigenous View," Acta Theologica 2 (2006).

33 Akinmayowa, Akino-Otiko \& Aremu Rahman, Abbas, "Return to African Traditional Religion after Conversion to Christianity or Islam: Patronage of Culture or Religious Conversion?" Ilorin Journal of Religious Studies 9, no.1 (2019): 28.

34 Akino-Otiko \& A. R. Abbas, "Return to African Traditional Religion," 28.

35 Akino-Otiko \& A. R. Abbas, "Return to African Traditional Religion, 28; cf. David Tuesday Adamo, "Christianity and the African Traditional Religion(s): The Postcolonial Round of Engagement." Verbum et Ecclesia 32, no.1 (2011), Art. \#285,10 pages, doi:10.4102/ve.v32i1.285; F. Hale, “Debating Igbo Conversion to Christianity: A Critical Indigenous View." Acta Theologica 2 (2006).

36 Togarasei, The Bible in Context, 96-97.

37 Akino-Otiko \& Abbas, "Return to African Traditional Religion, 29.

38 Akino-Otiko \& Abbas, "Return to African Traditional Religion, 27.
} 
attend to spiritual and material struggles in the daily lives of African people. It is the failure of the foreign religion to be a tool towards the struggles against life hazards and promises abundant security to its adherents. ${ }^{39}$

However, the author agrees with Togarasei that the conversion of Paul remains significant for Christianity despite its failure to be a prototype for the African's conversion to Christianity in the African context of the wellenshrined ATR. As Togarasei asserts, this conversion "is the second most important event in Christian history after the Christ event. Not only did it mark the beginning of Paul's Christian life, it also marked the beginning of Gentile Christianity which has seen the participation of Asians, Africans and all in Christianity. The conversion of Paul has also provided the church with a model of conversion." ${ }^{40}$ Despite the significance of this Damascus event in the history of Christianity as stipulated by Togarasei above, it remains uncompromising when it comes to the conversion of Africans towards the Christian religion as noted in what happens to the Rangi people of Tanzania and people of West Africa

Togarasei might be right when he says that Paul after his conversion made use of ideas from his Jewish and Hellenistic background to clarify the tenets of Christianity to his Gentile audience. It is also plausible that "were it not for Paul, Christianity would probably have remained a Jewish sect." ${ }^{41}$ Moreover, Togarasei is right when he considers the accusations of Africans returning to ATR while embracing Christianity by western-oriented pastors and theologians as being without justification because Paul himself hardly abandoned totally all the ideas of Judaism after his conversion to Christianity. ${ }^{42}$

What Togarasei seems to overlook is the difference between Paul's borrowing of ideas from Judaism and the way African Christians lapse to the ideas and practices of ATR. Togarasei's notion is that Africans are similarly borrowing from ATR as Paul borrowed from Judaism, and therefore, the conversion of Paul being a prototype for African's conversion to Christianity, a notion that lacks strength when one considers the purposes of borrowing. Paul borrowed from Judaism and Hellenism in order to make Christianity clearer to his Gentile audience, but Africans borrow from ATR because Christianity has failed to provide solutions to their daily life problems. Therefore, the two types of borrowing have no meeting points and should not be equated. Africans are not "following on the heels of Paul" 43 as Togarasei conceived; rather, they are forced by the inadequacy of the newly introduced religion that disregards their useful traditional ways of living.

\section{CONCLUSION}

This article commenced with the recognition of people's culture as a medium of conversion from one religion to another and situated the Damascus event and the conversion of Saul in the context of the Jewish culture. It has been discussed in this article that Saul as a Jew and a zealous defender of Judaism in the Pharisaic manner underwent conversion in two main stages necessary for it to take place: insight and transformation. Following these stages, Saul converted from Judaism to Christianity. Saul underwent a complete turn (metanoia) from being a zealous defender of the law to a zealous preacher of Christ to the Gentiles, and from a Pharisee to an apostle. Saul was converted to Christianity and called to ministry simultaneously. As Loba-Mkole praises him: "after his conversion, he became the most dedicated harbinger of the Gospel of Jesus Christ, the unbeatable advocate of the freedom in Christ (Ac 15:1-35; Gal 5:13) and the master-builder of several Christian communities." ${ }^{44}$ All these characteristics make Paul an excellent model of the church throughout its life on earth.

However, the article examined whether the conversion of Paul can be considered as a prototype to the conversion of Africans from ATR to Christianity. It defended the thesis that though the conversion of Paul has been regarded as a prototype for the conversion of people from other religions to Christianity, this conception can hardly be plausible for Africans and their cultural worldview. Two pieces of research have been used to illustrate this claim-one from Tanzania and another from Nigeria. The findings of these researches indicated that the conversion of an African from ATR to Christianity hardly separates him or her from the various practices rooted in the African culture. The failure of Christianity to provide sufficient answers to various problems facing Africans, and its more concern with the afterlife than this-life issues, make it insufficient to satisfy the requirements of Africans whose traditional religion is populated by various rituals and practices against hazards in their lives. Hence, the failure of the conversion of Paul to be a prototype for conversion of ATR adherents to Christianity indicates that Christianity, though embraced by a large number of people in Africa, is not yet fully made African.

In order for Christianity to be enshrined into African people's lives, the author suggests that, Paul's missionary strategy should rather be looked at and considered as a prototype for missionary work upon Africans and their ATR,

\footnotetext{
9 Banda, "The Sufficiency of Christ in Africa," 2.

Togarasei, The Bible in Context, 98-99; cf. Togarasei, "The Conversion of Paul," 124.

Togarasei, The Bible in Context, 110.

Togarasei, The Bible in Context, 110

Togarasei, The Bible in Context, 110.

Jean-Clause Loba-Mkole, "Paul and Africa?” HTS Teologiese Studies/Theological Studies 67, no.1 (2011): 5. Art. \#888, 11 pages. DOI: 10.4102/hts.v67i1.888.
} 
instead of looking at his conversion as a prototype for African's conversion to Christianity.

\begin{abstract}
ABOUT AUTHOR
Elia Shabani Mligo is Associate Professor of Contextual Theology and Research at Teofilo Kisanji University in Mbeya Tanzania. Prof. Mligo has published extensively in areas of Contextual Theology and Research. His currently published books include, but not limited to, the following: Women within Religions: Patriarchy, Feminism and the Role of Women in Selected World Religions (Eugene, OR: Wipf and Stock/Resource, 2020), Rediscovering Jesus in Our Places: Contextual Theology and Its Relevance to Contemporary Africa (Eugene, OR: Wipf and Stock/Resource, 2020), Writing Effective Course Assignments: A Guide to Non-Degree and Undergraduate Students (Eugene, OR: Wipf and Stock/Resource, 2016) and Introduction to Research Methods and Report Writing: A Practical Guide for Students and Researchers in Social Sciences and the Humanities (Eugene, OR: Wipf and Stock/Resource, 2016).
\end{abstract}

\title{
BIBLIOGRAPHY
}

Adamo, David Tuesday. "Christianity and the African Traditional Religion(s): The Postcolonial Round of Engagement.” Verbum et Ecclesia 32, no.1 (2011), Art.285, 10 pages. doi:10.4102/ve.v32i1.285.

Akino-Otiko, Akinmayowa \& Abbas, Aremu Rahman. "Return to African Traditional Religion after Conversion to Christianity or Islam: Patronage of Culture or Religious Conversion?" Ilorin Journal of Religious Studies 9, no.1 (2019): 27-36.

Amaladoss, Michael. "Religious Conversions: An Indian Christian Point of View." Hindu-Christian Studies Bulletin 15 (2002): 3-5.

Banda, Collium. "The Sufficiency of Christ in Africa: A Christological Challenge from African Traditional Religions." M.Th. Thesis, University of South Africa, 2005.

Bosch, J.D. Transforming Mission: Paradigm Shifts in Theology of Mission. New York, NY: Orbis, 1991.

Boz, Tuba. "Religious Conversion, Models and Paradigms." Epiphany: Journal of Transdisciplinary Studies 4, no.1 (2011): 128-145.

Cox, Richard. "Why Rangi Christians Continue to Practice African TraditionalReligion? GIALens 3 (2008). Accessed January 6, 2021. https://www.diu.edu/documents/gialens/Vol2-3/Cox-Why-Rangi-Christians-Pract ice-ATR.pdf

Dunn, James D.G. Jesus, Paul and the Law: Studies in Mark and Galatians. Philadelphia: Westminster, 1990.

Gaventa, Beverly R. From Darkness to Light: Aspects of Conversion in the New Testament. Philadelphia: Fortress, 1986.

Gration, John A. "Conversion in Cultural Context." International Bulletin of Missionary Research (1983): 157-162.

Ghansah, William Ekow. "Encounters between Christianity and African Traditional Religion in Fante Funeral Practices: A Critical Discussion of the Funeral Practices of the Fante in Ghana." M.Phil. Thesis, University of Oslo Norway, 2012.

Hale, F. "Debating Igbo Conversion to Christianity: A Critical Indigenous View." Acta Theologica 2 (2006): 116-135.

Kilbourne, Brock \& Richardson, James T. "Paradigm Conflict, Types of Conversion, and Conversion Theories." Sociological Analysis 50, no.1 (1988): 1 - 21

Loba-Mkole, Jean-Claude. "Paul and Africa?" HTS Teologiese Studies/Theological Studies 67, no.1 (2011) Art. 888, 11 pages. DOI: $10.4102 /$ hts.v67i1.888.

Longenecker, R.N. (ed.). The Road from Damascus: The Impact of Paul's Conversion on His Life, Thought and Ministry. Grand Rapids, MI: Eerdmans, 1997.

Mathole, Ezekiel Mokwele Katiso. "The Christian Witness in the Context of Poverty: With Special Reference to South African Charismatic Evangelicals.” PhD Thesis, University of Pretoria, South Africa, 2005.

Moe, David Thang. "Themes and Methodologies in Pauline Missiology for a Contemporary World." Missionalia 45. no. 2 (2017): 99-116.

Mugabe, H.J. "Salvation from an African Perspective." Evangelical Review of Theology 23/3 (1999): 238-247.

Munck, Johannes. Paul and the Salvation of Mankind. Atlanta, GA: John Knox, 1959.

Owineza, Marcel. "The Conversion of St. Paul.” Thinking Faith: The Online Journal of the British Jesuits(2011). Accessed January 6, 2021 https://www.thinkingfaith.org/articles/20110125 1.htm

Peace, Richard V. Conversion in the New Testament: Paul and the Twelve. Grand Rapids, MI: William B. Eerdmans, 1999. 
Pilch, John J. "Paul's Ecstatic Trance Experience near Damascus in Acts of the Apostles." HTS Teologiese Studies/ Theological Studies 58, no. 2 (2000): 690-707.

Rweyemamu, Josephat Alphonce. "Conversion in Missionary Christianity, Northwest Tanzania: A Critical Assessment of Methods and Their Impact on Haya Christian Life." PhD Thesis, University of Stellenbosch, South Africa, 2012.

Sewakpo, Honore, "A Comparative Analysis of Pre-conversion of Paul in Acts 8 - 9 and Boko Haram Insurgence in Nigeria: Implications for National Unity."

Smith, Gordon T. Beginning Well: Christian Conversion and Authentic Transformation. Downer Grove, IL: VIP Books, 2001.

Snow, David A. \& Machalek, Richard. "The Sociology of Conversion.” Annual Review of Sociology 10 (1984):167190.

. "The Convert as a Social Type.” In Sociological Theory, ed. Collins, R. San Francisco: Jossey Bass,1983.

Stendahl, Krister. Paul Among Jews and Gentiles and other Essays. Philadelphia: Fortress Press, 1976. . "The Apostle Paul and the Introspective Conscience of the West." Harvard Theological Review 56. no. 3 (1963): 199-215.

Togarasei, Lovemore. "The Conversion of Paul in the Light of the Theory of Cognitive Dissonance."Zambezia XXXI, no. i/ii (2004): 123-135.

. The Bible in Context: Essay Collection. BiAS 1. Bamberg: University of Bamberg Press, 2009. 